\title{
Characteristics of the Integration Process in the Food Industry of the Republic of Kazakhstan
}

\author{
Zarema Anvarovna ${ }^{1}$
}

\begin{abstract}
:
The article examines the problems of the integration processes in the food industry of Kazakhstan. It analyzes the current situation in the food and processing industries and describes the integration process in the food industry at the level of corporations. We reveal the problems of development in the food industry, including joint ventures, and highlight options to overcome them. The author concludes that creation of modern equipped territories embodied by industrial zones close to raw materials and distribution markets would be a positive step towards the creation of joint enterprises in the food industry.
\end{abstract}

Key Words: integration, food industry, joint ventures, the Customs Union (CU), the Common Economic Space (CES), the agroindustrial complex (AIC), the Eurasian Economic Union (EEU).

\footnotetext{
${ }^{1}$ Zarema Anvarovna, Karaganda Economic University, anvarovna.zarema@univglo.com
} 


\section{Introduction}

In view of the strengthening bonds and interdependence of national economies, the internationalization of economic life has shifted to a new stage of world economic relations, which are based on the introduction of national production factors into the single reproduction process on a global scale. Whereas developing on two levels, i.e. the global and the regional ones, the integration process is noted for by, on the one hand, an increment in the dependence of national economies on the global economy, and, on the other, by economic rapprochement of countries united as groups. The experience of inter-state unions shows that this is a compensation for the process of transnationalization of economies and produces good results in groups of countries that have similar levels of economic development.

Every national economy, including Kazakhstan, integrates into the global economy under the influence of general and specific factors conditioning this or that form of integration.

The Eurasian Economic Union creates special institutional conditions for the development of economy as a whole and of the AIC in particular. On the one hand, the boundaries of commodity markets are expanding, on the other, competition tightens, including the internal Kazakhstani market. This creates new external stimuli for food manufacturers to raise the quality of their produce and puts responsibility on the state for the adequacy of its support for producers, the orientation of their activities towards the modernization and assimilation of new economic technologies (Kostyunina, 2006).

The food industry of Kazakhstan is one of the most developed branches of the economy representing a considerable segment of the internal market and a focus on natural food and conventional technologies of agricultural production. On the other hand, the development of the food industry is hampered by these technologies and by small commodity production in agriculture. This prevents domestic food manufacturers from accessing EEU markets. Kazakhstan is one of the world's top 10 flour manufacturers but that is its only presence on the world's food market.

At the same time, a transfer of technologies in the food industry of Kazakhstan has become a widespread phenomenon. It has embraced every national manufacturer, whereas corporate integration, i.e. establishment of joint ventures, is still minor.

A start of a new period of development within the framework of a single institutional space with EEU countries may provide an impetus to the development of intercorporate integration of various kinds, ranging from the creation of joint enterprises to various sorts of alliances and network structures.

Examination of processes of inter-corporate integration as well as assessment of the influence of institutional space and the state's infrastructure policies on the rate and effect of formal and informal integration is a relevant topic of research. 


\section{Methodology}

Food industry is one of the strategic components of the national economy of any country. It is meant to provide a wide range of foodstuffs which correspond to the requirements and the living standards of various sections of society.

The development of food industry in Kazakhstan is important from the point of view of food security and the development of the agrarian sector of the economy since food-producing enterprises are large consumers of agricultural produce.

Over the years of independence, the food industry in Kazakhstan has undergone substantial changes, both in the structure of supply and in the makeup of economic entities. The list of such entities came to include companies from other countries and joint ventures. On the whole, this branch provides stability of the internal production market and its saturation with affordable food products.

The enhancement of the sector's competitiveness and its access to the markets of integration spaces will be determined by implementation of innovative technologies and products in the AIC and in the economy as a whole.

This study is based on the methods of ascent from the abstract to the concrete, analysis and synthesis, and systems analysis. We employed the methods of economic and statistical analysis (dynamic, structure, variation), comparative analysis and SWOT analysis.

\section{Review of literature}

The theoretical and practical issues of globalization, integration, transnationalization, problems of institutionalism, of the AIC and the food industry have been addressed by many international and Kazakhstani scientists.

The problems of transition to an innovative type of economic development have been analyzed by such sociologists and economists as Andre Gunder Frank(Frank, 1966), Immanuel Wallerstein(Wallerstein, 2004), Samir Amin (Amin, 1997), Giovanni Arrighi (Arrighi, 1999), T. Dos Santos(Dos Santos, 1973), Lin J (Lin, 2009), Barbier E (Barbier, 2007), in the context of external economic relations (EER) and the status of a country held in the global economy on the basis of combination of two approaches: the world-systems theory and the geo-economic approach (GEA).

The processes of globalization and internationalization have been examined by such scholars as S. Garmann 2014), M. Woods (Cheshire \& Woods, 2013), Farina E (Farina, 2000), Richard J. Barnet (Barnet \& Cavanagh, 1995), Karapinar, B(Karapinar \& Häberli, 2010), W. Rostow (Rostow, 1990), A. Libman (Libman, 
2007), Tylor W (Taylor, Schechter, \& Wolfson, 2007), Raynolds, L. T (Raynolds, 2004), Heyder (Heyder, Theuvsen, \& Hollmann-Hespos, 2012) and others.

The role of geography in economic processes has been investigated by such academic economists as P. Sunley (Martin \& Sunley, 2006), P. Krugman (Krugman, 1991), M. Porter (Porter, 2011), H Simpson (Devereux, Griffith, \& Simpson, 2004), E. Reinert (Reinert, 2007) and others.

The problems of institutionalism have been analyzed in the works of such scholars and economists as T. Veblen (Veblen, 2007), R. Coase (Coase, 1992) and D. North (North, 1986), Dequech D (Dequech, 2006), D Clark (Clark, Southern, \& Beer, 2007), L. Mises(Mises, 2013), F. Hayek (Hayek, 1948), M. Weber (Weber, 2002)and others. The institutional direction has been elaborated by Rebecka Engström (Engström, Nilsson, \& Finnveden, 2008) , Feindt P. (Feindt, 2012), Carsten Daugbjerg and Alan Swinbank (Daugbjerg \& Swinbank, 2012), Rykkja L. H. (Rykkja, 2004) and others.

In spite of the high level of elaboration of the above issues, the development of the food industry in conditions of integrative unification is a topical issue, and an adequate assessment is needed at present aimed at developing proposals on the enhancement of integration of the industry within the EEU framework in order to realize its potential.

\section{Results}

The Agreement on the Creation of the Eurasian Economic Union (EEU) came into force on January 1, 2015. It was signed by Russia, Belarus and on May 29, 2014. The Union embraces $170 \mathrm{mn}$ people, covers over $20 \mathrm{mn}$ sq. $\mathrm{km}$ of land (i.e. $15 \%$ of the Earth's surface), ranks first in the world in both gas production ( $22 \%$ of the world's gas) and oil extraction (14.6\% of the world's oil). The EEU ranks second in the world in fertilizer manufacturing (14\% of the world's share), third in electricity generation ( $9 \%$ of the world's electricity), fourth in both steel production $(6 \%$ of the world's steel) and coal-mining (6\% of the world's coal).

The EEU is a "model of a powerful subnational union capable of becoming a center of the modern world as well as an effective link between Europe and the dynamic Asia-Pacific Region." The union is an international organization of regional economic integration with an international legal status. This implies that the decisions of the Union and its bodies (e.g. the Economic Council, the Economic Commission, the Economic Court) have the status of norms of international law (Strategic Culture Foundation, 2013; Treshenkov E.E., 2014).

The final cause of integration processes is the creation of a single economic complex with regional labor distribution by the economic structures of the member states of 
the Union. This is coupled with a relatively high level of development of production forces and high intensity of mutual ties (Korzhov, 2008).

At the microlevel, the indicators of integrative processes are the following:

- the activity of joint ventures with foreign capital;

- cooperation ties that are formalized by contracts (of a consortium etc) and informal cooperation which functions as business connections with participation of economic entities of the member countries of the integrative space (Laslo V., 2014).

Whereas the first set of indicators can be assessed on the basis of official statistics, the second group needs expert evaluation and research.

The quantity, structure, the volume of production of joint enterprises in the food industry

Analysts observe an increase in the number of operating enterprises with participation of foreign capital in the processing industry, just like in the food industry, of the Republic of Kazakhstan.

Thus, in 2009-2013, the general number of operating enterprises with foreign capital in the processing industry increased by 994 enterprises (from 10,001 to 10,955), including an increase by 59 enterprises in the food industry (from 393 in 2009 to 452 in 2013) (Table 1).

Table 1. The share of joint ventures of the food industry among all joint ventures

\begin{tabular}{|l|l|l|l|l|l|}
\hline Year & 2009 & 2010 & 2011 & 2012 & 2013 \\
\hline $\begin{array}{l}\text { The number of operating enterprises with } \\
\text { participation of foreign capital in Kazakhstan, } \\
\text { units }\end{array}$ & 10001 & 10171 & 8504 & 8465 & 10955 \\
\hline $\begin{array}{l}\text { The number of operating enterprises with } \\
\text { participation of foreign capital in the food } \\
\text { industry, units }\end{array}$ & 393 & 422 & 441 & 458 & 452 \\
\hline Ratio,\% & 3.9 & 4.1 & 5.2 & 5.4 & 4.1 \\
\hline $\begin{array}{l}\text { Note - Compiled by the author according to data (Cabinet of Ministers of the Republic of } \\
\text { Kazakhstan, 2014c) }\end{array}$ \\
\hline
\end{tabular}

Thus, the number of joint ventures in the food industry in 2009 was $3.9 \%$ of the general number of joint ventures in Kazakhstan, whereas it was $4.1 \%$ in 2010 and 2013. This indicator reached its peak of $5.4 \%$ in 2012.

However, in absolute terms experts observed an upward trend in the quantity of joint ventures in the food industry from 2009 to 2012 and it was only in 2013 that their number somewhat reduced. 
Table 2 shows the number of enterprises in the food industry with the participation of foreign capital.

Table 2. The number of joint ventures in the food industry from 2009 to 2013 across Kazakhstan

\begin{tabular}{|c|c|c|c|c|c|}
\hline Year & 2009 & 2010 & 2011 & 2012 & 2013 \\
\hline Akmolinsk region & 4 & 10 & 10 & 11 & 12 \\
\hline Aktyubinsk region & 5 & 4 & 4 & 6 & 5 \\
\hline Almaty region & 16 & 21 & 27 & 25 & 28 \\
\hline Atyrau region & 5 & 4 & 5 & 6 & 6 \\
\hline $\begin{array}{l}\text { West Kazakhstan } \\
\text { region }\end{array}$ & 3 & 3 & 2 & 3 & 3 \\
\hline Jambyl region & 10 & 12 & 12 & 12 & 10 \\
\hline Karaganda region & 23 & 29 & 31 & 35 & 32 \\
\hline Kostanai region & 23 & 20 & 23 & 25 & 27 \\
\hline Kyzylorda region & 2 & 2 & 3 & 3 & 3 \\
\hline Mangistau region & 5 & 5 & 5 & 4 & 4 \\
\hline $\begin{array}{c}\text { South Kazakhstan } \\
\text { region }\end{array}$ & 49 & 53 & 48 & 50 & 49 \\
\hline Pavlodar region & 12 & 16 & 22 & 23 & 20 \\
\hline $\begin{array}{c}\text { North Kazakhstan } \\
\text { region }\end{array}$ & 15 & 16 & 19 & 21 & 21 \\
\hline East Kazakhstan region & 28 & 27 & 27 & 29 & 28 \\
\hline Astana city & 24 & 23 & 23 & 26 & 28 \\
\hline Almaty city & 169 & 177 & 180 & 179 & 176 \\
\hline Average value & 24,6 & 26,4 & 27,6 & 28,6 & 28,3 \\
\hline $\begin{array}{c}\text { Variation coefficient, } \\
\%\end{array}$ & 159 & 155 & 150 & 143 & 142 \\
\hline \multicolumn{6}{|c|}{$\begin{array}{l}\text { Note - Compiled by the author on the basis of the data on the } \\
\text { Committee on Statistics of the Republic of Kazakhstan (Cabinet of } \\
\text { Ministers of the Republic of Kazakhstan, 2014c) }\end{array}$} \\
\hline
\end{tabular}


Table 2 shows that the regions of Kazakhstan were heterogeneous from 2009 to 2013 as regards the number of joint ventures in the food industry. This is confirmed by the variation coefficient of over $30 \%$ over the entire period. At the same time, this coefficient decreased from $159 \%$ to $142 \%$ from 2009, which testifies to a tendency towards equability.

As can be seen in Picture 1, five regions led the way as regards joint ventures in the food industry:

- Almaty city (38.9\% of the general number of joint ventures in Kazakhstan);

- $\quad$ South Kazakhstan region (10.8 \%);

- Karaganda region (7.1\%);

- Almaty, East Kazakhstan regions, and Astana city (6.2\%);

- Kostanai region (6\%).

A comparison with the regional profile of joint ventures of all the branches of economy of Kazakhstan makes it possible to conclude that there are differences between the profiles.

If we should compare the seven regions leading with regard to all joint ventures and joint ventures in the food industry, the latter dominate in the agricultural regions which are adjacent to Russia (i.e. East Kazakhstan region, Kostanai, Pavlodar regions as well as North Kazakhstan region) and major population centers, namely Astana and Almaty, Shymkent, Karaganda. As expected, regions with adverse climatic conditions and weak or absent raw material bases have the least number of joint ventures in the food industry. These regions include Atyrau, Mangistau, West Kazakhstan, Kyzylorda and some other regions.

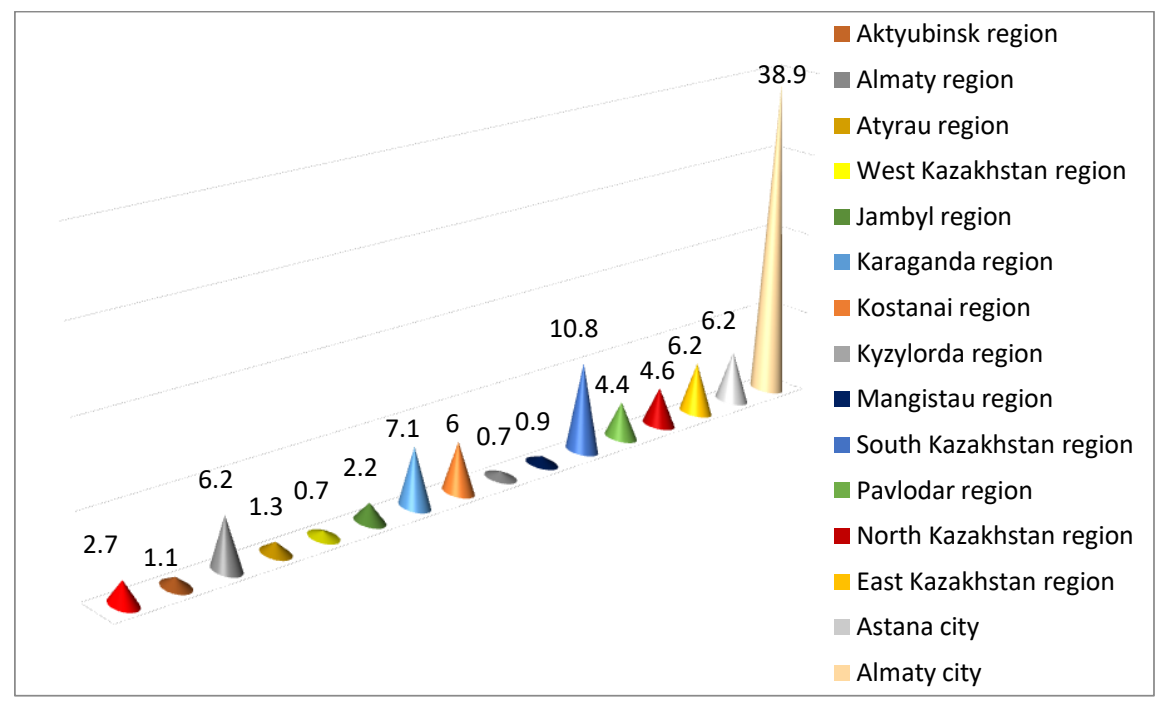


Figure 1. The ratio of joint ventures in the food industry in each region to the number of joint ventures in the food industry of Kazakhstan in 2013, \% (Note Compiled by the author according to data Note - Compiled by the author according to data (Cabinet of Ministers of the Republic of Kazakhstan, 2014c)

The number of joint ventures according to the main kinds of manufactured produce is presented in Table 3.

Table 3. The number of joint ventures according to the kinds of manufactured produce in Kazakhstan as a whole and by year

\begin{tabular}{|l|l|l|l|l|l|}
\hline \multicolumn{1}{|c|}{ Year } & 2009 & 2010 & 2011 & 2012 & 2013 \\
\hline $\begin{array}{l}\text { Processing and canning } \\
\text { of meat and } \\
\text { manufacture of meat } \\
\text { products }\end{array}$ & 42 & 36 & 44 & 43 & 42 \\
\hline $\begin{array}{l}\text { Processing and canning } \\
\text { of fish, crustaceans and } \\
\text { shell-fish }\end{array}$ & 11 & 14 & 16 & 16 & 15 \\
\hline $\begin{array}{l}\text { Processing and canning } \\
\text { fruit and vegetables }\end{array}$ & 15 & 15 & 16 & 16 & 16 \\
\hline $\begin{array}{l}\text { Production of } \\
\text { vegetable and animal } \\
\text { oils and fats }\end{array}$ & 16 & 15 & 16 & 17 & 16 \\
\hline $\begin{array}{l}\text { Dairy manufacture } \\
\text { Manufacture of the } \\
\text { products of the flour- } \\
\text { milling industry, } \\
\text { starches and starch } \\
\text { products }\end{array}$ & 92 & 92 & 89 & 97 & 95 \\
\hline $\begin{array}{l}\text { Manufacture of bread } \\
\text { and other } \\
\text { products }\end{array}$ & 125 & 152 & 159 & 164 & 161 \\
\hline $\begin{array}{l}\text { Manufacture of other } \\
\text { foodstuffs }\end{array}$ & 52 & 50 & 52 & 57 & 56 \\
\hline $\begin{array}{l}\text { Manufacture of ready- } \\
\text { made feeds for animals }\end{array}$ & 11 & 11 & 13 & 12 & 13 \\
\hline Beverage production & 58 & 82 & 79 & 80 & 80 \\
\hline
\end{tabular}




\begin{tabular}{|l|l|l|l|l|l|}
\hline $\begin{array}{l}\text { Production of tobacco } \\
\text { goods }\end{array}$ & 3 & 3 & 3 & 4 & 3 \\
\hline Total & 454 & 507 & 523 & 542 & 535 \\
\hline
\end{tabular}

Table 3 suggests that joint ventures manufacturing bread and other flour products take the lead among all the joint ventures of Kazakhstan. Thus, their number increased by 36 enterprises from 2009 to 2013. Joint ventures for the manufacture of products of the flour-milling industry, starches and starch products hold the second place, amounting to 95 enterprises in 2013. The number of joint ventures in the manufacture of beverages increased 1.38 times (from 58 enterprises in 2009 to 80 enterprises in 2013). A small number of joint enterprises are engaged in the manufacture of tobacco products.

As for the production output in the food industry of Kazakhstan, it is characterized by slight but steady growth. Compared to 2009, production grew by an equivalent of USD 27. $782 \mathrm{mn}$ in 2013. The indicators of the output of food products by enterprises with foreign capital suggest quite dynamic growth from 2009 to 2011. The year 2012, however, was characterized by a decline in production, which showed positive dynamics again in 2013. Thus, the output of enterprises with foreign capital in 2013 grew 1.22 times in comparison with 2009. The ratio of the production output of enterprises with foreign capital to the general output of the food industry is characterized by a tendency of cyclicality of growth and decline. The maximum proportion of the manufacture of food products by joint ventures in the whole food industry was observed also in 2009-2011. Specifically, it amounted to 5.8-6\%, after which a decline to $4.5-4.8 \%$ was observed (see Table 4).

Table 4. The volume of manufacture of foodstuffs by joint ventures within the food industry.

\begin{tabular}{|c|c|c|c|c|c|}
\hline & 2009 & 2010 & 2011 & 2012 & 2013 \\
\hline $\begin{array}{c}\text { Output in the food industry } \\
\text { of Kazakhstan, USD }\end{array}$ & $2.051 \mathrm{bn}$ & $2.265 \mathrm{bn}$ & $2.697 \mathrm{bn}$ & $2.819 \mathrm{bn}$ & $3.160 \mathrm{bn}$ \\
\hline $\begin{array}{c}\text { Manufacture of foodstuffs by } \\
\text { enterprises with foreign } \\
\text { capital, USD }\end{array}$ & $123 \mathrm{mn}$ & $131 \mathrm{mn}$ & $164 \mathrm{mn}$ & $128 \mathrm{mn}$ & $152 \mathrm{mn}$ \\
\hline Proportion, \% & 6 & 5.8 & 6 & 4.5 & 4.8 \\
\hline
\end{tabular}

Note - Compiled by the author according to the collection Industries of Kazakhstan and Its Regions 2009-2013» (Cabinet of Ministers of the Republic of Kazakhstan, 2014c) 
Thus, analyzing the activities of enterprises with participation of foreign capital in the Republic of Kazakhstan, we may conclude:

- We observe growth in the proportion of joint ventures for the manufacture of food products among joint ventures with participation of foreign capital. This testifies to the development of integration. Thus, the proportion of joint ventures in the food industry in 2009 was $3.9 \%$ of the general number of joint ventures in Kazakhstan, and $4.1 \%$ in 2010 and 2013.

- The proportions of joint enterprises in the food industry in the regions of Kazakhstan are different, with the value of the variation coefficient ranging from -33.8 to $-17.1 \%$ in $2009-2013$. Moreover, five regions in Kazakhstan led the way in terms of joint ventures in the food industry in 2013.

1. Almaty city $(38.9 \%$ of the general number of joint ventures in Kazakhstan);

2. South Kazakhstan region $(10.8 \%)$.

3. Karaganda region $(7.1 \%)$.

4. Almaty, East Kazakhstan regions and Astana city (6.2\%).

5. Kostanai region $(6 \%)$.

Moreover, the regions which are adjacent to Russia prevail in the development of the food industry. They include such agricultural regions as East Kazakhstan, Kostanai, Pavlodar, North Kazakhstan regions and major population centers (Astana, Almaty, Shymkent, Karaganda). As was expected of the food industry which leans towards markets of consumers and raw materials bases, the regions with adverse climatic conditions, weak or absent raw materials bases (Atyrau, Mangistau, South Kazakhstan, Kyzylordy and other regions) have the least number of joint enterprises of the food sector.

-Joint ventures that manufacture bread and flour products are the most numerous among joint ventures in Kazakhstan. Thus, their number increased by 36 enterprises from 2009 to 2013. Joint ventures of the flour-milling industry, starches and starch products ranked second with 95 enterprises in 2013. The number of joint ventures in the beverages industry increased by 1.38 times (from 58 enterprises in 2009 to 80 enterprises in 2013). The manufacture of tobacco products displayed the least number of joint ventures.

- The dynamics of production in the food industry of the Republic of Kazakhstan is characterized by slight but stable growth. Compared to 2009, the volume of production grew by USD $27.782 \mathrm{mn}$ in 2013.

Large cities, which consume a lot of products and services, are centers of gravity for joint ventures. Therefore it is necessary to create well-equipped areas in the form of industrial zones which would be close to both sources of raw materials and commodity markets (Cabinet of Ministers of the Republic of Kazakhstan, 2013; KAZAGRO, 2015). 


\section{Conclusion}

The impact of the development of the world economy is felt not only on the global but also on national levels. We speak of the strengthening of interdependence and mutual influence of the economies of different countries regardless of their level of development and systems of government as a common movement to a single global economy and an integrated system. The global character of the development of the world economy is an objective process which provides for the formation and development of a single economic space, interrelated functioning of global commodity markets, markets of information and knowledge, capital and labor. This is demonstrated by partner countries which are members of an integrated structure (Khusainov, 2011).

The processes of globalization taking place in the world are invariably noted for the enhancement of international and regional economic integration. The Eurasian economic integration is no exception. Within the framework of their Union, Russia, Belarus and Kazakhstan intend to set up joint enterprises as well as cooperate in the scientific-technical and technological domains. The development of the food industry, processing industry and innovation production is one of the most important tasks facing Russia, Belarus and Kazakhstan - the three member states of the Eurasian Economic Union. If this plan is successfully implemented, the member states will be able to enhance the competitiveness of their respective economies and raise the level of their citizens' welfare.

\section{References}

Amin, S. 1997, "Capitalism in the age of globalization: The management of contemporary society" (Zed Books).

Arrighi, G. 1999, "Chaos and governance in the modern world system" (U of Minnesota Press).

Barbier, E. B. 2007, "Natural resources and economic development" (Cambridge University Press).

Barnet, R. J., \& Cavanagh, J. 1995, "Global dreams: Imperial corporations and the new world order" (Simon and Schuster).

Cabinet of Ministers of the Republic of Kazakhstan. 2013, "Kazakhstan and CIS countries".

Cabinet of Ministers of the Republic of Kazakhstan. 2014a, "Investment and construction activity in the Republic of Kazakhstan 2009-2013".

Cabinet of Ministers of the Republic of Kazakhstan. 2014b, "Science and innovation activity of Kazakhstan" 2009-2013.

Cabinet of Ministers of the Republic of Kazakhstan. 2014c, "The industry of Kazakhstan and its regions: 2009-2013".

Cheshire, L., \& Woods, M. 2013, "Globally engaged farmers as transnational actors: Navigating the landscape of agri-food globalization", Geoforum, 44, 232-242.

Clark, D., Southern, R., \& Beer, J. 2007, "Rural governance, community empowerment and the new institutionalism: A case study of the Isle of Wight", Journal of Rural Studies, 23(2), 254-266.

Coase, R. H. 1992, "The institutional structure of production", The American Economic 


\section{Z. Anvarovna}

Review, 82(4), 713-719.

Daugbjerg, C., \& Swinbank, A. 2012, "An introduction to the "new"politics of agriculture and food", Policy and Society, 31(4), 259-270.

Dequech, D. 2006, "The new institutional economics and the theory of behaviour under uncertainty", Journal of Economic Behavior \& Organization, 59(1), 109-131.

Devereux, M. P., Griffith, R., \& Simpson, H. 2004, "The geographic distribution of production activity in the UK", Regional Science and Urban Economics, 34(5), 533564.

Dos Santos, T. 1973, "The crisis of development theory and the problem of dependence in Latin America", Underdevelopment and Development, 57-79.

Engström, R., Nilsson, M., \& Finnveden, G. 2008, "Which environmental problems get policy attention? Examining energy and agricultural sector policies in Sweden", Environmental Impact Assessment Review, 28(4), 241-255.

Farina, E. M. M. Q. 2000, "Challenges for Brazil's food industry in the context of globalization and Mercosur consolidation", The International Food and Agribusiness Management Review, 2(3), 315-330.

Feindt, P. H. 2012, "The politics of biopatents in food and agriculture, 1950-2010: Value conflict, competing paradigms and contested institutionalisation in multi-level governance", Policy and Society, 31(4), 281-293.

Frank, A. G. 1966, "The development of underdevelopment" (New England Free Press Boston, MA).

Garmann, S. 2014, "Does globalization influence protectionism? Empirical evidence from agricultural support", Food Policy, 49, 281-293.

Hayek, F. A. 1948, "Individualism and economic order" (University of chicago Press).

Heyder, M., Theuvsen, L., \& Hollmann-Hespos, T. 2012, 'Investments in tracking and tracing systems in the food industry: A PLS analysis", Food Policy, 37(1), 102-113.

Karapinar, B., \& Häberli, C. 2010, "Food crises and the WTO: world trade forum" (Cambridge University Press).

KAZAGRO 2015,. Kazakhstani hospitability.

Khusainov, B. D. 2011. "Country preferences and competitiveness of exports from Belarus, Kazakhstan and Russia", Eurasian Economic Integration., 2(11), 71-96.

Korzhov, A. I. 2008, "Strategic priorities of the innovation agriculture sector of the economy of Kazakhstan in conditions of integration on the CIS terrain" (Moscow: Nauka).

Kostyunina, G. M. 2006, "A general description of the integration tendencies in developing countries". In International economic integration: a study guide (pp. 219-226) (Moscow: Economics).

Krugman, P. R. 1991, "Geography and trade" (MIT press).

Laslo V., N. Z. A. 2014, "Trends in the development of integrative unions of economic agents in the food industry", Gazette of Regional Development, 3-4(37), 33-45.

Libman, A. 2007, "Regionalisation and regionalism in the post-Soviet space: Current status and implications for institutional development", Europe-Asia Studies, 59(3), 401-430.

Lin, J. Y. 2009, "Economic development and transition: thought, strategy, and viability" (Cambridge University Press).

Martin, R., \& Sunley, P. 2006, "Path dependence and regional economic evolution", Journal of Economic Geography, 6(4), 395-437.

Mises, L. von. 2013, "Omnipotent government" (Read Books Ltd).

North, D. C. 1986, "The new institutional economics", Journal of Institutional and Theoretical Economics (JITE)/Zeitschrift Für Die Gesamte Staatswissenschaft, 142(1), 230-237. 
Porter, M. E. 2011, "Competitive advantage of nations: creating and sustaining superior performance" (Simon and Schuster).

Raynolds, L. T. 2004, "The globalization of organic agro-food networks", World Development, 32(5), 725-743.

Reinert, E. S. 2007, "How rich countries got rich... and why poor countries stay poor" (Constable London).

Rostow, W. W. 1990, "The stages of economic growth: A non-communist manifesto" (Cambridge university press).

Rykkja, L. H. 2004, "Independent food agencies-restoring confidence", Policy and Society, 23(4), 125-148.

Strategic Culture Foundation. 2013, "Start of the EEU", Retrieved from http://ukraina.ru/analytics/20141231/ 1011678175. html

Taylor, W. W., Schechter, M. G., \& Wolfson, L. G. 2007, "Globalization: Effects on fisheries resources" (Cambridge University Press).

Treshenkov E.E. 2014, "European and Eurasian models of integration: bounds of commensurability", World Economy and International Relations, 5, 31-41.

Veblen, T. 2007, "The theory of the leisure class" (OUP Oxford).

Wallerstein, I. M. 2004, "World-systems analysis: An introduction" (Duke University Press).

Weber, M. 2002, "The Protestant Ethic and the Spirit of Capitalism: and other writings" (Penguin). 